\title{
THE VALUE OF BLINK REFLEX IN EARLY DIAGNOSIS OF MULTIPLE SCLEROSIS
}

\author{
Lidija Dežmalj Grbelja ${ }^{1}$, Ivan Mikula ${ }^{2}$, Lejla Ćorić ${ }^{1}$, Maristela Stojić ${ }^{3}$ and Vida Demarin ${ }^{4}$ \\ ${ }^{1}$ Department of Neurology, Sestre milosrdnice University Hospital Centre, Zagreb, Croatia; \\ ${ }^{2}$ Sveta Katarina Polyclinic, Zagreb, Croatia; \\ ${ }^{3}$ Department of Neurology, Dubrava University Hospital, Zagreb, Croatia; \\ ${ }^{4}$ Croatian Academy of Sciences and Arts, Zagreb, Croatia
}

\begin{abstract}
SUMMARY - The aim was to determine differences of blink reflex in clinically definite multiple sclerosis (CDMS) and clinically isolated syndrome (CIS) in patients presented with symptoms and signs of brainstem impairment. The study included 20 patients diagnosed with CDMS, 20 with CIS, and 20 healthy controls. We recorded latencies of early (R1) and late component ipsilaterally (R2) and contralaterally (R2'), and occurrence of irritative component (R3). We analyzed data on sex, age, signs of brainstem impairment and magnetic resonance imaging (MRI) findings for the presence of brainstem demyelinating lesions. There was no statistically significant difference between patient groups according to sex, age, symptoms of brainstem involvement and MRI findings. There was no statistically significant difference in $\mathrm{R} 1$ component latencies and $\mathrm{R} 2$ latencies on the right side. Latencies of $\mathrm{R} 2$ on the left and R2' on the right were statistically longer in CDMS group. There was no difference in the appearance of R3 component. In conclusion, blink reflex was found to be a very sensitive and useful diagnostic tool in the assessment of brainstem structures, especially because abnormalities are seen not only in CDMS but also in CIS. Slowing of the late component as a sign of dysfunction in the efferent part of the reflex arc is not very specific but is a highly sensitive finding.
\end{abstract}

Key words: Blink reflex; Brainstem; Clinically isolated syndrome; Multiple sclerosis

\section{Introduction}

Multiple sclerosis (MS) is a chronic disease of the central nervous system (CNS) characterized by the loss of myelin sheath and their axons and concurrent inflammatory reaction. The main pathophysiological feature of demyelinating process is slowing of impulse conduction along a demyelinated fiber, which results in different clinical signs and symptoms. Modern neurophysiologic techniques are used to assess very precisely and exactly nerve conduction velocity across sensory pathways in the $\mathrm{CNS}^{1-4}$. However, in the era of magnetic resonance imaging (MRI), they are insuffi-

Correspondence to: Lidija Dežmalj Grbelja, PhD, Department of Neurology, Sestre milosrdnice University Hospital Centre, Vinogradska c. 29, HR-10000 Zagreb, Croatia

E-mail: lidija.dezmaljgrbelja@gmail.com

Received December 3, 2018, accepted July 22, 2019 ciently used. Visual evoked potentials (VEP), which are one of McDonald's criteria for the diagnosis of MS, are most frequently used ${ }^{5,6}$. In 2016, new guidelines for MRI in MS diagnostics (MAGNIMS) were accepted, according to which slowing of conductivity in VEP findings was confirmed as dissemination in time and space in the absence of visual symptoms ${ }^{7}$.

Blink reflex (BR) dates back to 1896, when it was introduced by Overend, a British physician ${ }^{8}$. Until 1952, its electrophysiologic mechanism was unexplained. Kugelber performed it stimulating the supraorbital nerve and showed two components of the reflex arc, i.e. early R1, which is unilateral, appears after 1015 ms ipsilaterally on the stimulating side of ophthalmic branch of trigeminal nerve, clinically it is not visible; and late R2 component, which is bilateral and appears after 30- to 35-ms latency; it presents with blinking. The third component, R3, which is consid- 
ered nociceptive, can sometimes be recorded. Afferent part of the reflex arc is ophthalmic branch of trigeminal nerve and efferent part belongs to the facial nerve'.

Stimulating ophthalmic branch impulse is conducted across the pons (R1 component). Synaptic arc includes one or two interneurons to the principal sensory trigeminal nucleus. Afferent part of R2 component passes through descendent spinal trigeminal tract across pons and medulla oblongata to the caudal spinal trigeminal nucleus, then ascending bilaterally to pontine facial nuclei. Neurophysiologic studies of BR provide useful information on brainstem function including trigeminal and facial nerves and cranial part of the spinal $\operatorname{cord}^{10}$.

In this study, we assessed neurophysiologic characteristics of BR in patients with clinically definite multiple sclerosis (CDMS) and those with clinically isolated syndrome (CIS) presenting with symptoms of brainstem involvement. We aimed to determine differences in BR between these two patient groups comparing them to the control group, and to prove that $\mathrm{BR}$ is a useful diagnostic tool in brainstem assessment.

\section{Subjects and Methods}

We examined 20 patients diagnosed with CDMS and confirmed according to the modified McDonald's criteria, 20 patients diagnosed with CIS presenting with symptoms of brainstem involvement, and 20 healthy controls. The study was approved by the Ethics Committee of the Sestre milosrdnice University Hospital Centre and performed in accordance with ethical standards laid down in the 1964 Declaration of Helsinki. All subjects signed an informed consent prior to inclusion in the investigation. The study was performed at Department of Neurology, Sestre milosrdnice University Hospital Centre, Zagreb, Croatia, during 14 months (March 2016 until May 2017). Exclusion criteria were infectious, traumatic, neoplastic or vascular lesions of brainstem, idiopathic trigeminal neuralgia, neuropathies, dystonia, or taking medications that could affect BR including triptans or clonidine. For this reason, we took thorough disease history and neurological examination. The presence of clinical signs and symptoms of brainstem lesions including impairment of extraocular movements, nystagmus, trigeminal damage, facial weakness, hearing loss, dysarthria, dysphagia was tested. Laboratory testing included erythrocyte sedimentation rate, complete blood cell count, glucose, electrolytes, serum gamma-glutamyltranspeptidase (SGGT), serum glutamic-oxaloacetictransaminase (SGOT) and serum glutamic-pyruvictransaminase (SGPT). Chest $\mathrm{x}$-ray was performed. We also analyzed retrospectively MRI findings, obtained not more than three months before the study, with special analysis of brainstem structures (mesencephalon, pons and medulla oblongata). MRI was performed on a $1.5 \mathrm{~T}$ device. Control group included 20 healthy volunteers, employees at the Department of Neurology, Sestre milosrdnice University Hospital Centre. They underwent neurological examination and BR analysis.

Analysis of BR was performed using Neuropack equipment with cup electrodes in the sitting position with open eyes. Active electrode was placed above the lateral part of the orbicular muscle of eye and reference electrode above the lower part of the orbicular muscle of eye on both sides. A non-cephalic ground electrode was placed over the left wrist. We used supramaximal electric stimulation with single stimulus of $15-20 \mathrm{~mA}$ (sweep $100 \mathrm{~ms}$, division $10 \mathrm{~ms}$, gain $5 \mathrm{mV}$ ) of the supraorbital branch of trigeminal nerve ipsilaterally and contralaterally. Stimulation was done at intervals of seven seconds, between spontaneous closing of eyelids. We recorded electric response on the orbicular muscle of eye bilaterally. We recorded latencies of R1 and R2 components ipsilaterally and contralaterally (R2'), along with the appearance of irritative $\mathrm{R} 3$ component.

\section{Statistics}

The median, lowest and highest values of latencies for R1, R2 and R2' components of BR were calculated in all groups of subjects. Parametric methods including Student's t-test and descriptive methods such as arithmetic mean and standard deviation were used for normally distributed data, whereas non-parametric methods, Wilcoxon test and $\chi^{2}$-test were used on statistical analysis of non-normally distributed data.

\section{Results}

We analyzed data on sex and age, presence of brainstem symptoms, as well as MRI findings of brainstem structure in the MS and CIS groups (Table 1).

The MS group consisted of 20 patients, 9 men and 11 women, mean age 37.45 (range 18-53) years, SD 11.02; CIS group consisted of 20 patients, 7 men and 
Table 1. Data on sex, age, presence of brainstem symptoms and MRI findings in brainstem structure

\begin{tabular}{|l|l|l|l|l|}
\hline Group & Mean age (yrs) & Sex & Brainstem symptoms, n (\%) & $\begin{array}{l}\text { MRI } \\
\text { n, (\%) }\end{array}$ \\
\hline Multiple sclerosis & 37.45 & $\begin{array}{l}9 \mathrm{M} \\
11 \mathrm{~F}\end{array}$ & $\begin{array}{l}\text { Vertigo, 7 (35\%) } \\
\text { Diplopia, 4 (20\%) } \\
\text { Facial sensory disturbances, 4 (20\%) } \\
\text { Gait instability, 4 (15\%) } \\
\text { Dysarthria, 2 (10\%) }\end{array}$ & $8(40 \%)$ \\
\hline $\begin{array}{l}\text { Clinically isolated } \\
\text { syndrome }\end{array}$ & 30.35 & $7 \mathrm{M}$ & $\begin{array}{l}\text { Diplopia, 8 (40\%) } \\
\text { Vertigo, 6 (30\%) } \\
\text { Facial sensory disturbances, 3 (15\%) } \\
\text { Trigeminal neuralgia, 2 (10\%) } \\
\text { Dysarthria, 1 (5\%) }\end{array}$ & $7(35 \%)$ \\
\hline Control & 29.6 & $\begin{array}{l}\text { 6 M } \\
14 \mathrm{~F}\end{array}$ & & \\
\hline
\end{tabular}

MRI = magnetic resonance imaging; $M=$ male $F=$ female

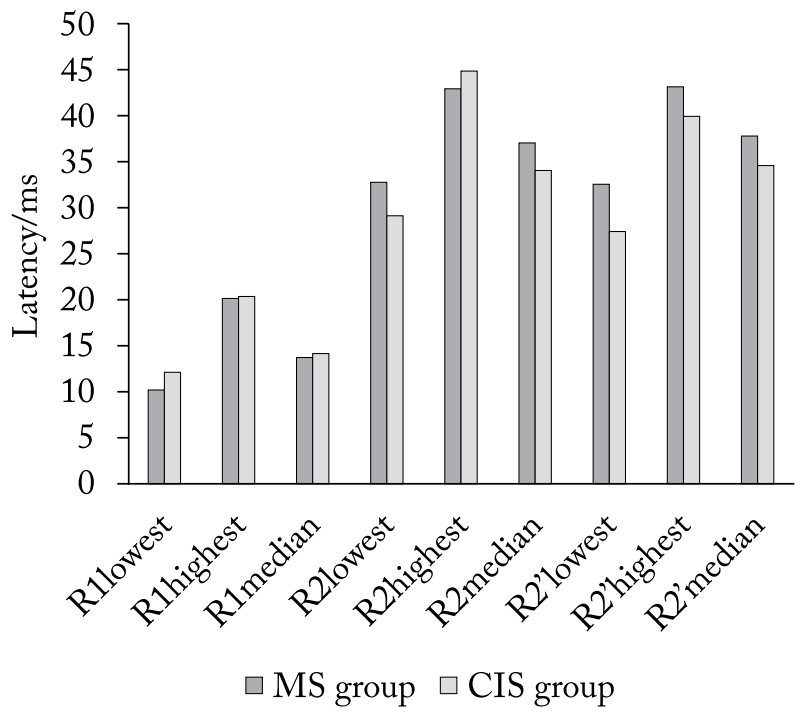

Fig. 1. The lowest, highest and median values of latencies of $R 1, R 2$ and $R 2$ ' components on the right side.

MS = multiple sclerosis; CIS = clinically isolated syndrome; R1= early component of blink reflex; R2 = late component of blink reflex ipsilaterally; R2' = late component of blink reflex contralaterally

13 women, mean age 30.35 (range 19-56) years, SD 9.06; and control group consisted of 6 men and 14 women, mean age 29.6 (range 20-38) years, SD 4.16.

There was no statistically significant difference in the presence of symptoms and signs of brainstem lesions between MS and CIS groups $(\mathrm{p}=0.774)$. The signs and symptoms of brainstem lesions were present in eight (40\%) MS patients and seven (35\%) CIS pa- tients. In MS group, vertigo was the most common symptom, recorded in seven (35\%) patients, followed by diplopia in four (20\%), facial sensory disturbances in four (20\%), gait instability in three (15\%) and dysarthria in two (10\%) patients. Diplopia was the most common symptom in CIS group, found in eight (40\%) patients, followed by vertigo in six (30\%), facial sensory disturbances in three (15\%), trigeminal neuralgia in two (10\%) patients and dysarthria in one $(5 \%) \mathrm{pa}-$ tient. MRI analysis of brainstem structures showed the presence of demyelinating lesions in 12 (60\%) MS patients and eight (40\%) CIS patients. There was no statistically significant difference in MRI distribution of brainstem lesions between MS and CIS groups $(\mathrm{p}=0.930)$.

Figure 1 shows median, lowest and highest values of latencies of R1, R2 and R2' components on the right side in MS group and CIS group, and Figure 2 shows the respective values on the left side.

Using Student's t-test, we found no significant difference in R1 latency either on the right ( $p=0.746)$ or on the left side $(\mathrm{p}=0.784)$. The same results were found for R2 latencies on the right side ( $\mathrm{p}=0.193)$, whereas on the left side we found longer R2 latency in MS group, with a statistically significant difference ( $p=0.018)$. In MS group, latencies of R2' component on the right side were also significantly longer $(\mathrm{p}=0.003)$. There was no difference in latencies of R2' component on the left side $(\mathrm{p}=0.185)$. The third R3 component was found in one MS patient bilaterally, 


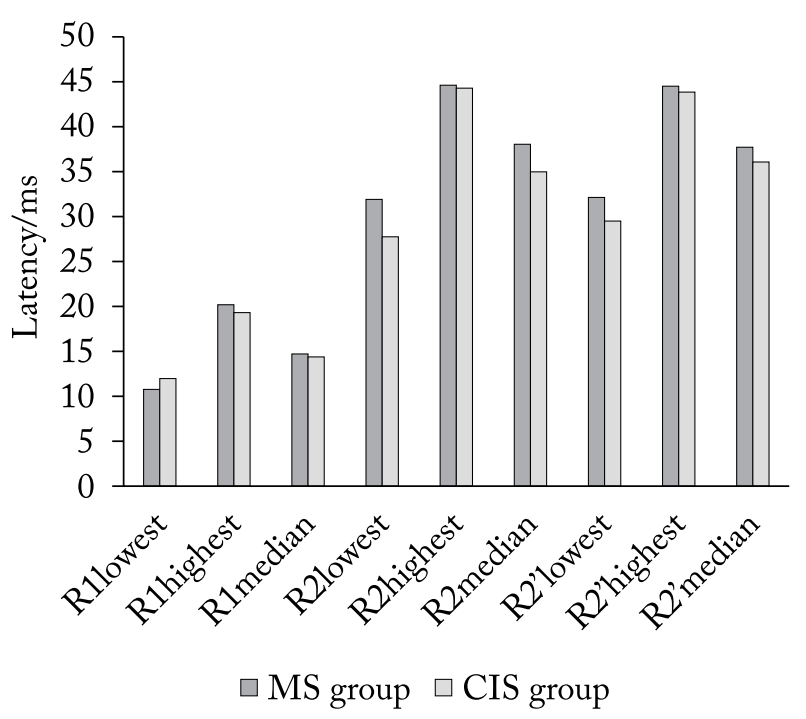

Fig. 2. The lowest, highest and median values of latencies of $R 1, R 2$ and $R 2$ ' components on the left side.

MS = multiple sclerosis; CIS = clinically isolated syndrome; R1 = early component of blink reflex; R2 = late component of blink reflex ipsilaterally; R2' = late component of blink reflex contralaterally

and the same was found in CIS group on the right side. In CIS group, R3 on the left side was found in three patients. There was no statistically significant difference in the appearance of the third component between the two patient groups ( $\mathrm{p}=0.315$ ).

Comparing MS with control group, we found statistically significantly prolonged latencies of $\mathrm{R} 1$ ( $\mathrm{p}=0.035)$ and $\mathrm{R} 2(\mathrm{p}=0.022)$ on the right side, and of $\mathrm{R} 2$ ( $\mathrm{p}=0.045)$ and R2' ( $\mathrm{p}=0.005)$ on the left side. Comparing CIS group with control group, we found statistically significantly prolonged latencies of $\mathrm{R} 2(\mathrm{p}=0.015)$ and R2' ( $p=0.027$ ) on the right side, and of $\mathrm{R} 2$ $(\mathrm{p}=0.003)$ on the left side.

\section{Discussion}

Our results showed that average value of latencies of $\mathrm{R} 1$ component in both groups were within the normal range, i.e. $\leq 15 \mathrm{~ms}$. Average latencies of $\mathrm{R} 2$ component were prolonged ( $\geq 35 \mathrm{~ms}$ ) in both groups on both sides except for latencies of R2 in CIS group on the left side, which were within the normal range. Average latencies of R2' component in MS group were also prolonged on both sides $(\geq 40 \mathrm{~ms})$, whereas in CIS group they were prolonged on the left side and within the normal range on the right side. Comparing the re- sults between MS and CIS groups, we found statistically significant differences for R2 component on the left side, which were more prolonged in MS group ( $p=0.018$ ), and for R2' component on the right side $(\mathrm{p}=0.003)$. We found a statistically significant difference in the latency of the examined BR components in both groups compared to the control group, which confirmed the sensitivity of this method in functional brainstem investigation. The distribution of single or simultaneous involvement of multiple components was very heterogeneous, as confirmed by literature data $^{11}$. The above can be explained by different infratentorial localization of demyelinating lesions, as well as the suprasegmental influence of basal ganglia and cerebral cortex on the trigeminofacial complex ${ }^{12}$. Previous studies of BR in MS have shown that demyelinating lesions in the brainstem cause electrophysiologic abnormalities of $\mathrm{BR}$, which present as slowing of R1 and/or R2 latency, lowering of amplitude or occurrence of third irritative R3 component as a manifestation of paroxysmal painful phenomenon or trigeminal neuralgia ${ }^{13}$. Analysis of BR can detect abnormalities which have not clear clinical equivalent, so the additional importance of this diagnostic method is the possibility to detect so called 'silent' lesions.

Although the sensitivity of BR in MS has been confirmed in several previous studies, as well as other neurophysiological methods, MRI has proved to be superior in the confirmation of dissemination in time and space ${ }^{14,15}$. In our study, MRI results showed brainstem lesions in $60 \%$ of MS patients and $40 \%$ of CIS patients, with no statistical difference between the two groups. Despite the high sensitivity of MRI, there is still a significant number of patients with clear clinical signs but no neuroradiological equivalent that would explain their presence, considered to be a clinical-radiological paradox ${ }^{16,17}$. For that reason, there is a need to introduce additional diagnostic options that would clarify the occurrence of neurological symptoms for which there is no radiological correlation.

Recent data found in the literature suggest that $30 \%-45 \%$ of MS patients have brainstem symptoms, which is consistent with our results ${ }^{18}$. Although involvement of brainstem is common in MS, isolated cranial nerve palsies as a symptom of MS relapse are rare. They occurred more often as a symptom of CIS ${ }^{19}$. Symptoms of brainstem lesions, including diplopia, vertigo or trigeminal neuralgia, are very often found as a symptom in CDMS and in CIS. Sastre-Garriga et al. 
analyzed brainstem manifestations in CIS and found that diplopia was present in $68 \%$, facial sensory symptoms in $32 \%$, and gait disturbance in $31 \%$ of patients ${ }^{20}$. They also found that the total number of brainstem symptoms was not predictive for conversion to CDMS. Isolated presence of facial sensory symptoms showed a lower risk of conversion ${ }^{21}$. However, knowing that brainstem involvement means earlier conversion to CDMS and a higher risk of disease progression, we have to look for a method that could provide more information about brainstem functional involvement. Our study suggests that a diagnostic tool such as electrophysiologic analysis of BR could give us a lot of information about brainstem structure and transmission of electric impulse between nuclei that are included in that pathway.

\section{Conclusion}

In conclusion, we can say that BR is a very sensitive and useful diagnostic tool in the assessment of brainstem structure, especially because abnormalities are seen not only in CDMS but also in CIS as the first clinical manifestation of the disease. Although not very specific, slowing of late $\mathrm{R} 2$ component as a result of dysfunction of the efferent part of reflex arc is a highly sensitive finding in BR analysis.

\section{References}

1. Comi G, Leocani L, Medaglini S, et al. Measuring evoked response in multiple sclerosis. Mult Scler. 1999;5(4):263-7.

2. Fischer C, André-Obadia N, Mauguiére F. Diagnostic criteria of multiple sclerosis: electrophysiological criteria. Rev Neurol. 2001;157(8-9Pt2):974-80.

3. Gabelić T, Krbot Skorić M, Adamec I, et al. The vestibular evoked myogenic potentials (VEMP) score: a promising tool for evaluation of brainstem involvement in multiple sclerosis. Eur J Neurol. 2015;22(2):261-9. doi: 10.1111/ene.12557. Epub 2014 Sep 8.

4. Ivanković A, Nesek Mađarić V, Starčević K, et al. Auditory evoked potentials and vestibular evoked myogenic potentials in evaluation of brainstem lesions in multiple sclerosis. J Neurol Sci. 2013;328(1-2):24-7. doi: 10.1016/j.jns.2013.02.005. Epub 2013 Mar 13.

5. Polman CH, Reingold SC, Banwell B, et al. Diagnostic criteria for multiple sclerosis: 2010 revision to the McDonald criteria. Ann Neurol. 2011;69(2):292-302. doi: 10.1002/ana.22366.

6. Acar G, Ozakbas S, Cakmakci H, Idiman F, Idiman E. Visual evoked potential is superior to triple dose magnetic resonance imaging in the diagnosis of optic nerve involvement. Int J Neurosci. 2004;114(8);1025-33.

7. Filippi M, Rocca MA, Ciccarelli O, et al. MRI criteria for the diagnosis of multiple sclerosis: MAGNIMS consensus guidelines. Lancet Neurol. 2016;15(3):292-303. doi: 10.1016/ S1474-4422(15)00393-2. Epub 2016 Jan 26.

8. Pearce JM. Observations on the blink reflex. Eur Neurol. 2008; 59(3-4):221-3. doi: 10.1159/000114053. Epub 2008 Jan 29.

9. Esteban A. A neurophysiological approach to brainstem reflexes. Blink reflex. Neurophysiol Clin. 1999;29(1):7-38.

10. Aramideh M, Ongerboer de Visser BW. Brainstem reflexes: electrodiagnostic techniques, physiology, normative data, and clinical applications. Muscle Nerve. 2002;26(1):14-30.

11. Brooks JB, Jardim MR, Papais-Alvarenga RM, Fragoso YD. There is still a role for the blink reflex in the diagnosis and follow up of multiple sclerosis. Clin Neurophysiol. 2015;126(4): 743-7. doi: 10.1016/j.clinph.2014.06.050. Epub 2014 Aug 19.

12. Mikropoulos EH, Papathanasiou AA, Hadjigeorgiou G, Tsironi E, Papadimitriou A. Supratentorial multiple sclerosis lesions affect the blink reflex test. Open Neurol J. 2010;4:92-9. doi: 10.2174/1874205X01004010092.

13. Hooge JP, Redekop WK. Trigeminal neuralgia in multiple sclerosis. Neurology. 1995;45:1294-6.

14. Magnano I, Pes GM, Pilurzi G, et al. Exploring brainstem function in multiple sclerosis by combining brainstem reflexes, evoked potentials, clinical and MRI investigations. Clin Neurophysiol. 2014;125(11):2286-96. doi: 10.1016/j.clinph.2014. 03.016. Epub 2014 Mar 25.

15. Skorić MK, Adamec I, Mađarić VN, Habek M. Evaluation of brainstem involvement in multiple sclerosis. Can J Neurol Sci. 2014;41(3):346-9.

16. Hackmack K, Weygandt M, Wuerfel J, et al. Can we overcome the 'clinico-radiological paradox' in multiple sclerosis? J Neurol. 2012 Oct;259(10):2151-60. doi: 10.1007/s00415-012-6475-9. Epub 2012 Mar 24.

17. Mollison D, Sellar R, Bastin M, et al. The clinico-radiological paradox of cognitive function and MRI burden of white matter lesions in people with multiple sclerosis: a systematic review and meta-analysis. PLoS One. 2017;12(5)e0177727. doi: 10.1371/journal.pone.0177727. eCollection 2017.

18. Habek M. Evaluation of brainstem involvement in multiple sclerosis. Exp Rev Neurother. 2013;13(3):299-311. doi: 10.1586/ern.13.18.

19. Thömke F, Lensch E, Ringel K, Hopf HC. Isolated cranial nerve palsies in multiple sclerosis. J Neurol Neurosurg Psychiatry. 1997;63:682-5.

20. Sastre-Garriga J, Tintoré M, Nos C, et al. Clinical features of CIS of the brainstem/cerebellum of the kind seen in MS. J Neurol. 2010;257:1432-59. Epub 2009 Nov 28.

21. Sastre-Garriga J, Tintoré M, Rovira A, et al. Conversion to multiple sclerosis after a clinically isolated syndrome of the brainstem: cranial magnetic resonance imaging, cerebrospinal fluid and neurophysiological findings. Mult Scler. 2003;9(1): 39-43. 
Sažetak

\section{VRIJEDNOST REFLEKSA TREPTAJA U RANOJ DIJAGNOSTICI MULTIPLE SKLEROZE}

\section{Dežmalj Grbelja, I. Mikula, L. Ćoric, M. Stojić i V. Demarin}

Cilj je bio ispitati razliku refleksa treptaja u bolesnika s dijagnozom klinički definitivne multiple skleroze (CDMS) i klinički izoliranog sindroma (CIS) koji imaju simptome i znakove oštećenja moždanog debla. Istraživanje je obuhvatilo 20 bolesnika s dijagnozom CDMS, 20 s CIS i 20 zdravih ispitanika kao kontrolna skupina. Bilježili smo latencije rane (R1) i kasne komponente ipsilateralno (R2) i kontralateralno (R2'), kao i pojavu iritativne komponente (R3). Analizirali smo spol, dob, simptome i znakove oštećenja moždanog debla, nalaz magnetske rezonancije (MR) s obzirom na prisustvo demijelinizacijskih lezija u području moždanog debla. Nije utvrđena razlika među skupinama bolesnika s obzirom na spol, dob, prisustvo simptoma oštećenja moždanog debla te nalaz MR. Nije bilo razlike u latencijama komponente R1, kao ni u latencijama R2 na desnoj strani. Latencije komponente R2 na lijevoj strani i R2' na desnoj strani bile su statistički duže u skupini ispitanika s CDMS. Nije bilo razlike u pojavnosti komponente R3. U zaključku, refleks treptaja je vrlo osjetljiv i koristan dijagnostički alat za procjenu funkcije moždanog debla, pogotovo zbog toga što se abnormalnosti ne vide samo u CDMS, nego i u CIS. Usporenje kasne komponente kao znak disfunkcije eferentnog dijela refleksnog luka, iako nije specifičan nalaz, pokazao se kao vrlo osjetljiv nalaz.

Ključne riječi: Klinički izolirani sindrom; Moždano deblo; Multipla skleroza; Refleks treptaja 